\title{
Cell Membrane Modification for Rapid Display of Bi-Functional Peptides: A Novel Approach to Reduce Complement Activation
}

\author{
Ledia Goga ${ }^{1}$, Gustavo Perez-Abadia ${ }^{1}$, Sathnur B Pushpakumar ${ }^{1}$, Daniel Cramer ${ }^{2}$, Jun Yan ${ }^{2}$, \\ Nathan Todnem ${ }^{1}$, Gary Anderson ${ }^{1}$, Chirag Soni ${ }^{1}$, John Barker ${ }^{3}$ and Claudio Maldonado ${ }^{1, *}$ \\ ${ }^{I}$ Department of Physiology and Biophysics \\ ${ }^{2}$ Department of Tumor Immunobiology \\ ${ }^{3}$ Department of Surgery, University of Louisville, Louisville, KY 40292, USA
}

\begin{abstract}
Ischemia and reperfusion of organs is an unavoidable consequence of transplantation. Inflammatory events associated with reperfusion injury are in part attributed to excessive complement activation. Systemic administration of complement inhibitors reduces reperfusion injury but leaves patients vulnerable to infection. Here, we report a novel therapeutic strategy that decorates cells with an anti-complement peptide. An analog of the $\mathrm{C} 3$ convertase inhibitor Compstatin $(\mathrm{C})$ was synthesized with a hexahistidine $\left(\mathrm{His}_{6}\right)$ tag to create $\mathrm{C}-\mathrm{His}_{6}$. To decorate cell membranes with $\mathrm{C}-\mathrm{His}_{6}$, fusogenic lipid vesicles (FLVs) were used to incorporate lipids with nickel $\left(\mathrm{Ni}^{2+}\right)$ tethers into cell membranes, and these could then couple with $\mathrm{C}-\mathrm{His}_{6} . \mathrm{Ni}^{2+}$ tether levels to display $\mathrm{C}-\mathrm{His}_{6}$ were modulated by changing FLV formulation, FLV incubation time and FLV levels. SKOV-3 cells decorated with $\mathrm{C}^{-} \mathrm{His}_{6}$ effectively reduced complement deposition in a classical complement activation assay. We conclude that our therapeutic approach appears promising for local ex vivo treatment of transplanted organs to reduce complement-mediated reperfusion injury.
\end{abstract}

Keywords: Complement, Complement inhibitors, Compstatin, Drug delivery, Liposomes, Ischemia, Reperfusion, Cell membrane.

\section{INTRODUCTION}

Since the original description of complement activation observed in ischemic hearts [1], there is growing evidence that complement is a central mediator of ischemia/reperfusion (IR) injury (IRI) [2-4]. After decades of neglect, complement has been rediscovered as a potent mediator of inflammation and rejection in organ transplants. Studies have shown that IR-induced complement activation leads to the formation of several key inflammatory mediators that alter vascular homeostasis and stimulate leukocyte activation and chemotaxis [2, 4-6]. Depending on the type of tissue involved, IR-induced complement activation may occur via the classical and/or alternative pathways [4, 7]. Under normal conditions, the vascular endothelial cells express CD59, CD46, CD55 and C receptor 1 (CR1), which offer protection against constant low-level complement activation in plasma [8]. However, following organ transplantation, the inevitable IR activates complement to greater levels than normal, rapidly overwhelming natural anti-complement defenses. To curtail IR-induced or unwanted complement activation, soluble forms of CR1, CD59, CD46 and CD55 have been developed $[9,10]$, but due to their non-specific nature these agents inactivate complement systemically thereby placing the recipients at increased risk of iatrogenic disease.

At present, second generation agents aimed at targeting specific cells or tissues are being developed for clinical use

\footnotetext{
*Address correspondence to this author at the Department of Physiology and Biophysics, University of Louisville, Louisville, Kentucky 40292 USA; Tel: 502-852-1078; Fax: 502-852-1256;

E-mail: cjmald01@louisville.edu, cjmald01@gmail.com
}

[11-15]. However, the success rate has been disappointingly low. Some of these targeted agents continue to have drawbacks, including: 1) Systemic delivery with generalized complement suppression; 2) Dosing issues due to dependence on expression levels of targeted membrane proteins, which varies between individuals and/or in the presence of pathological conditions; and 3) Cost effectiveness of recombinant protein products requiring multiple manufacturing steps, which may prove prohibitive for clinical use [11]. To address these issues, we developed a novel and relatively inexpensive therapeutic approach for the local delivery of synthetic anti-complement peptides to be used in transplantation or in by-pass procedures. Our approach takes advantage of an inherent property of small unilamellar fusogenic lipid vesicles (FLVs) [16], which when fusing with cells incorporate their lipids into cell membranes. FLVs are formulated with a mixture of three lipids, one of them containing a nickel $\left(\mathrm{Ni}^{2+}\right)$ tether. After FLVs fuse with cells, $\mathrm{Ni}^{2+}$ tethers are displayed on the membrane surface and can be used as linkers to decorate cells with a bi-functional peptide comprised of a hexahistidine $\left(\mathrm{His}_{6}\right) \mathrm{Ni}^{2+}$-tether-binding domain and an anti-complement domain. Liposomes formulated with lipids containing functional groups to bind proteins or antibodies for either targeting or to increase fusogenicity have been previously reported (reviewed in reference [17]). Liposomes formulated with a metal chelating lipid have been incubated with tumor cells with the purpose of displaying recombinant co-stimulatory proteins for potential use as anticancer vaccines [18]. To our knowledge, the use of FLVs to display anti-complement peptides on the surface of cell membranes to control complement activation has not been reported previously. 
The purpose of this study was to determine whether a therapeutic strategy based on the decoration of cells with a small bi-functional anti-complement peptide would be effective in reducing complement deposition in vitro. Compstatin (C), a small peptide known to inhibit classical or alternative C3 convertase by preventing C3 cleavage [19-22], was selected to create a bi-functional analog by adding a $\mathrm{His}_{6}$-tag to $\mathrm{C}$ and produce $\mathrm{C}-\mathrm{His}_{6}$. Here, we report that cells treated with FLVs containing $\mathrm{Ni}^{2+}$ tethers and incubated with $\mathrm{C}-\mathrm{His}_{6}$, displayed the bi-functional peptide on cell membranes and effectively reduced complement deposition in a classical activation assay.

\section{MATERIALS AND METHODS}

\section{C-His ${ }_{6}$ Synthesis}

The original $\mathrm{C}$ peptide sequence Ile1-[Cys2-Val3-Val4Gln5-Asp6-Trp7-Gly8-His9-His10-Arg11-Cys12]-Thr13-NH2 was modified as previously described to increase potency with substitutions: Val4 to 2-naphthylalanine (2Nal) and His9 to Ala [23]. Furthermore, a His ${ }_{6}$-tag was added to the C-terminus of the peptide. Solid phase peptide synthesis using Fmoc strategy on a Rink amide resin was used to synthesize $\mathrm{C}-\mathrm{His}_{6}$. The peptide was purified using HPLC.

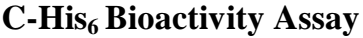

Antibody-sensitized sheep erythrocytes (Sigma-Aldrich, St. Louis, MO) were used to perform a hemolytic complement assay to test $\mathrm{C}-\mathrm{His}_{6}$ inhibition. The cells were washed and re-suspended in Gelatin Veronal Buffer (GVB) (SigmaAldrich, St. Louis, MO) at a concentration of $1 \times 10^{8}$ cells $/ \mathrm{mL}$ and then aliquoted in a 96 well microtiter plate at $100 \mu \mathrm{L} /$ well. C-His 6 was serially diluted in 1:20 human serum/GVB from $0.015 \mu \mathrm{M}$ to $0.0039 \mu \mathrm{M}$ in $2: 3$ parts/volume ratio. $100 \mu \mathrm{L}$ of this solution was then added to the cells and incubated with constant shaking for an hour at $37^{\circ} \mathrm{C}$. $150 \mu \mathrm{L}$ of ice-cold GVB was added to all the wells to inhibit further complement activity. The plate was then centrifuged at $800 \mathrm{G}$ for $10 \mathrm{~min}$ at $4{ }^{\circ} \mathrm{C}$. After removing the supernatants, they were transferred to a 96 well microtiter plate and absorbance readings were obtained at $414 \mathrm{~nm}$. The $100 \%$ lysis value was obtained by suspending cells in water and the minimal value was obtained by suspending cells in GVB only.

\section{Cell Culture}

Human skin fibroblasts were cultured in Dulbecco's Modified Eagle's Medium (DMEM) (Sigma Inc. St Louis, MO) supplemented with: 10\% Fetal Bovine Serum (FBS), $2 \mathrm{mM}$ L-Glutamine and $100 \mathrm{U} / \mathrm{mL}$ of Penicillin/Streptomycin mixture. Ovarian carcinoma (SKOV-3) cells were incubated in McCoy's Complete Medium (Caisson Labs, North Logan, UT) with $10 \%$ FBS, $2 \mathrm{mM}$ L-Glutamine and $100 \mathrm{U} / \mathrm{mL}$ of Penicillin/Streptomycin. Both cell types were then seeded in $75 \mathrm{~cm}^{2}$ flasks and maintained in a tissue culture incubator at $37^{\circ} \mathrm{C}$ with $5 \% \mathrm{CO}_{2}$ and $90 \%$ humidity.

\section{Fusogenic Lipid Vesicle Synthesis}

FLVs were formulated with various molar ratios of 1,2Dioleoyl-sn-Glycero-3-Phosphocholine (DOPC), 1-Palmitoyl2-Oleoyl-sn-Glycero-3-Phosphate (Monosodium Salt) (POPA) and 1,2-Dioleoyl-sn-glycero-3-\{[N(5-amino-1-carboxypentyl) iminodiacetic acid] Succinyl (Nickel Salt) (DOGS-NTA$\mathrm{Ni}^{2+}$ ) (Avanti Polar Lipids, Alabaster, AL). The molar ratios of DOPC, POPA, and DOGS-NTA-Ni ${ }^{2+}$ were varied to optimize $\mathrm{Ni}^{2+}$ tether incorporation onto cell membranes. Lipids in liquid chloroform were mixed in a glass flask, and the mixture was dried under nitrogen gas. The mixture was further desiccated overnight in a vacuum chamber. The lipids were rehydrated in $\mathrm{Ca}^{2+} / \mathrm{Mg}^{2+}$-free PBS buffer at a concentration of $1 \mathrm{mg} / \mathrm{mL}$, vortexed for $1 \mathrm{~min}$ and incubated in a $37^{\circ} \mathrm{C}$ bath for $5 \mathrm{~min}$. This cycle was repeated 6 times, and the resulting solutions of multi-lamellar lipid vesicles were sonicated with a Branson Sonifier® 450A (Branson Ultrasonics Corp, Danbury, CT) at $50 \%$ duty cycle for $1 \mathrm{~min} / \mathrm{mL}$ to form smaller unilamellar FLVs.

\section{Functionalization of Cell Membranes with $\mathrm{Ni}^{2+}$ Tethers}

These experiments were performed using fibroblasts and SKOV-3 cells. FLV formulations were optimized using fibroblasts because of their hardiness and excellent ability to remain attached to well bottoms. Subsequent experiments were conducted on SKOV-3 cells to characterize the effects of FLV levels and incubation time prior to performance of complement deposition studies on these cells. FLV formulations were optimized by varying the molar ratio of DOGSNTA-Ni ${ }^{2+}$ thus changing the final levels of $\mathrm{Ni}^{2+}$ chelated lipid from 40 to $87 \mathrm{ng} / \mu \mathrm{L}$. Fibroblasts were first seeded in a 96 well microplate coated with $0.5 \%$ porcine gelatin solution (Sigma-Aldrich, St. Louis, MO) at a density of $8 \times 10^{4}$ cells/well and incubated for $12 \mathrm{hr}$ at $37^{\circ} \mathrm{C}$ with $5 \% \mathrm{CO}_{2}$ and $90 \%$ humidity. Cells were then washed twice with PBS and treated for 20 min with FLVs formulated with the following DOGS-NTA-Ni ${ }^{2+}$ concentrations: 40, 52, 64, 75 and 87 $\mathrm{ng} / \mu \mathrm{L}$. Eight wells per lipid concentration were tested. To assess $\mathrm{Ni}^{2+}$ tether incorporation, cells were incubated for $30 \mathrm{~min}$ with $0.2 \mathrm{ng} / \mu \mathrm{L}$ of truncated $\mathrm{His}_{6}$-Cardiotrophin (BioVendor Laboratory Medicine, Inc. Brno, Czech Republic) and with $0.01 \mu \mathrm{g} / \mu \mathrm{L}$ of FITC- labeled anti-His ${ }_{6}$ antibody (Alpha Diagnostic, San Antonio, TX) for 15 min. (His ${ }_{6}^{-}$ Cardiotrophin was used as a probe to demonstrate that other His $_{6}$-tagged agents would couple to lipid-tethered $\mathrm{Ni}^{2+}$ and that the FITC- labeled anti-His 6 antibody was an effective method to quantify $\mathrm{Ni}^{2+}$ tethers on membranes). All the wells were washed thrice with PBS between incubation treatments. Background controls did not receive FLVs but were incubated with $\mathrm{His}_{6}$-Cardiotrophin and FITC- labeled anti-His 6 antibody. Antibody-specific fluorescence was measured using a SpectraMax M2 (Molecular Devices, Sunnyvale, CA) microplate reader at $494 \mathrm{~nm}$ excitation and $518 \mathrm{~nm}$ emission. Reported values were corrected for background.

Similar experiments were performed with SKOV-3 ovarian carcinoma cells to determine the effect of FLV concentration on tether incorporation and $\mathrm{C}-\mathrm{His}_{6}$ binding. Cells were seeded at a density of $8 \times 10^{4}$ cells/well in 96 well microplates and exposed for $20 \mathrm{~min}$ to FLVs formulated with $64 \mathrm{ng} / \mu \mathrm{L}$ DOGS-NTA-Ni ${ }^{2+}$ diluted in PBS to achieve final lipid concentrations ranging from 12.5 to $500 \mu \mathrm{g} / \mathrm{mL}$. Cells were incubated with $0.01 \mu \mathrm{g} / \mu \mathrm{L}$ of $\mathrm{C}-\mathrm{His}_{6}$ for $30 \mathrm{~min}$ and with FITC- labeled anti-His ${ }_{6}$ antibody for $15 \mathrm{~min}$. All wells were washed thrice between steps, and fluorescence was measured as above. 
The relation between FLV incubation time and incorporation of $\mathrm{Ni}^{2+}$ tethers was characterized by incubating SKOV-3 cells for 10 to 50 min with FLVs $(500 \mu \mathrm{g} / \mathrm{mL})$ formulated with DOGS-NTA-Ni ${ }^{2+}(64 \mathrm{ng} / \mu \mathrm{L})$. Cells were incubated with $0.01 \mu \mathrm{g} / \mu \mathrm{L}$ of $\mathrm{C}_{-\mathrm{His}_{6}}$ for $30 \mathrm{~min}$ and with FITClabeled anti-His ${ }_{6}$ antibody for $15 \mathrm{~min}$. All wells were washed thrice between steps, and fluorescence was measured as described above.

\section{Quantification of C-His ${ }_{6}$ Levels on Cell Membranes}

To quantify $\mathrm{C}-\mathrm{His}_{6}$ levels displayed on cell membranes following $\mathrm{FLV} / \mathrm{C}-\mathrm{His}_{6}$ treatment, a direct analysis assay using UV absorbance was performed on a SpectraMax M2 (Molecular Devices) microplate reader. The assay was based on detecting the $2 \mathrm{Nal}$ residue of the $\mathrm{C}$-His ${ }_{6}$ sequence, which we estimated to have a peak absorbance in the $280-290 \mathrm{~nm}$ range. To determine the optimal wavelength for $\mathrm{C}-\mathrm{His}_{6} \mathrm{ab}-$ sorbance, various concentrations of the peptide were serially diluted in half starting at $0.2 \mu \mathrm{g} / \mu \mathrm{L}$ and ending at $0.00625 \mu \mathrm{g} /$ $\mu \mathrm{L}$. Three $100 \mu \mathrm{L}$ aliquots per dilution were placed on a 96-well plate. The UV absorbance was measured repeatedly at $2 \mathrm{~nm}$ increments starting at $270 \mathrm{~nm}$ until a maximum difference between dilutions was observed, measurements continued at higher wavelengths until differences between samples were no longer apparent at $300 \mathrm{~nm}$.

To quantify membrane-bound C-His 6 levels, SKOV-3 cells were seeded in Costar 12 well plates and allowed to reach confluence. Cells were incubated for $50 \mathrm{~min}$ with FLVs $(500 \mu \mathrm{g} / \mathrm{mL})$ and without FLVs. All cells were washed thrice and incubated with $1 \mathrm{~mL}$ of $0.10 \mu \mathrm{g} / \mu \mathrm{L}$ of $\mathrm{C}-\mathrm{His}_{6}$ for $30 \mathrm{~min}$. Cells were washed thrice, and to release membranebound $\mathrm{C}-H i s_{6}$, cells were incubated with $330 \mu \mathrm{L}$ of PBS $(\mathrm{pH}$ 4) for $10 \mathrm{~min} .100 \mu \mathrm{L}$ from each well were drawn, placed in a 96 well microplate and UV absorbance was measured at 284 $\mathrm{nm}$. The mean absorbance values were converted to C-His 6 levels using a standard curve of known concentrations and adjusted to levels per mL. C-His ${ }_{6}$ levels per membrane area were calculated using the well's bottom surface area $\left(38.3 \mathrm{~mm}^{2}\right)$ under the assumption that this area was equivalent to the cells' non-adherent membrane area at $100 \%$ confluence.

\section{Time Course Experiments}

To determine the duration of $\mathrm{C}$-His ${ }_{6}$ display on cell membranes, fibroblasts were seeded in Costar 12 well plates and allowed to reach $\sim 90 \%$ confluence. Cells were incubated for $30 \mathrm{~min}$ with FLVs $(500 \mu \mathrm{g} / \mathrm{mL})$ and without FLVs. All cells were washed twice and incubated with $1 \mathrm{~mL}$ of 0.1 $\mathrm{mg} / \mathrm{mL}$ of C-His ${ }_{6}$ for $30 \mathrm{~min}$. Cells were washed and incubated in cell media. Levels of $\mathrm{C}$-His ${ }_{6}$ were quantified after treatment, at 24 and 48 hours. The same methods used to quantify $\mathrm{C}$-His ${ }_{6}$ levels displayed on cell membranes in the C$\mathrm{His}_{6}$ quantification section above were used in these experiments. Membrane-bound $\mathrm{C}-\mathrm{His}_{6}$ was released by incubating cells in $330 \mu \mathrm{L}$ of PBS ( $\mathrm{pH} 4$ ) for $10 \mathrm{~min}$. Three $100 \mu \mathrm{L}$ aliquots from each well were drawn, placed in separate wells in a 96 well microplate, and UV absorbance was measured at $284 \mathrm{~nm}$. Absorbance values were converted to C-His ${ }_{6}$ levels in solution using a standard curve, and levels of peptide at the various time points were compared. The experiment was repeated five times and the results were averaged.

\section{Complement C3b Deposition Assay}

We used the protocol described by B.P. Morgan with some modifications to quantify the inhibitory effect of CHis $_{6}$ [24]. SKOV-3 cells were seeded in 96 well microtiter plates and allowed to reach $90 \%$ confluence. Cell membranes were functionalized with $\mathrm{Ni}^{2+}$ tethers by incubating for 40 min with FLVs containing $64 \mathrm{ng} / \mu \mathrm{L}$ of DOGS-NTA$\mathrm{Ni}^{2+}$. Cells were subsequently incubated for $30 \mathrm{~min}$ with various concentrations of $\mathrm{C}-\mathrm{His}_{6}(0.05-0.2 \mu \mathrm{g} / \mu \mathrm{L})$. Control cells did not receive any treatment. Cells were then lifted off the plate with Cellstripper ${ }^{\mathrm{TM}}$ (Mediatech Inc Herndon, VA), washed in $3 \%$ BSA/PBS and re-suspended at $1 \times 10^{6}$ cells $/ \mathrm{mL}$ in flow cytometry tubes. Trastuzumab (Herceptin) was then added at $0.05 \mu \mathrm{g} / \mu \mathrm{L}$ and the cells were kept at $4^{\circ} \mathrm{C}$ for 30 min. Each tube was washed with $2 \mathrm{~mL}$ of McCoy's medium, centrifuged at $300 \mathrm{G}$ for $10 \mathrm{~min}$ and re-suspended in 1:2 dilution of fresh human serum. The samples were subsequently incubated at $37^{\circ} \mathrm{C}, 5 \% \mathrm{CO}_{2}, 90 \%$ humidity for $30 \mathrm{~min}$ with intermittent agitation, washed again in minimal media (M119, 1\%FBS) and re-suspended in 1:100 dilution FITCconjugated goat anti-human $\mathrm{F}(\mathrm{ab}$ ')2 fragment antibody to $\mathrm{C} 3$ (MP-Biomedicals, Solomon, $\mathrm{OH}$ ). The cells were kept at $4^{\circ} \mathrm{C}$ for $30 \mathrm{~min}$ then centrifuged for $5 \mathrm{~min}$ at $300 \mathrm{G}$ at $4{ }^{\circ} \mathrm{C}$, and re-suspended in $500 \mu \mathrm{L}$ of minimal media. $10 \mu \mathrm{L}$ of propidium iodide (PI) was added to identify dead cells. All cells were washed with PBS between treatment steps. Control groups without $\mathrm{C}-\mathrm{His}_{6}$ were included to assess spontaneous complement deposition, non-specific antibody binding, and maximal complement deposition. PI-positive cells were excluded from the analyzed sample and fluorescence emitted by live cells in the FITC channel was quantified for control and experimental groups using the FlowJo software program (Tree Star, Inc., Ashland, OR).

\section{Statistical Analysis}

Data from formulation, concentration and incubation time experiments were analyzed for statistical significance by a one-way ANOVA followed by post-hoc pairwise comparisons. Differences between control groups and experimental groups were evaluated using Tukey's test. In experiments in which two groups were being compared, a student's t-test was performed. The differences between treatment and control groups as measured by flow cytometry was determined with a chi-square univariate analysis (FlowJo, version 8.8.6) [25]. A $\mathrm{P}$ value of $<0.05$ was considered significant. Data is reported as means \pm SEM.

\section{RESULTS}

\section{Bioactivity of C-His 6}

Once C-His 6 was synthesized and purified to $>95 \%$ purity, the peptide was tested for bioactivity using a hemolytic complement assay. The normalized dose response relationship between $\mathrm{C}-\mathrm{His}_{6}$ concentration and hemolytic inhibition are shown in Fig. (1). The $\mathrm{EC}_{50}$ was $9.37 \mathrm{nM}$ indicating that modification with a $\mathrm{His}_{6}$ tag did not render $\mathrm{C}-\mathrm{His}_{6}$ inactive. 


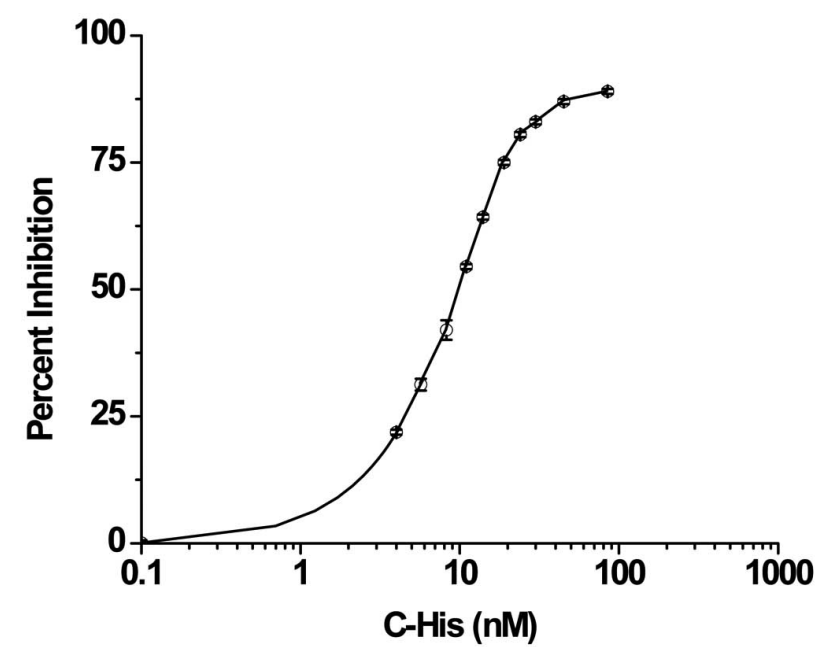

Fig. (1). C-His ${ }_{6}$ inhibition curve of complement mediated erythrocyte lysis. Antibody sensitized sheep erythrocytes were suspended in 1:20 human serum/gelatin veronal buffer (GVB) and treated with serial dilutions of $\mathrm{C}-\mathrm{His}_{6}$. The $100 \%$ lysis value was obtained by suspending cells in water and the minimal value was obtained by suspending cells in GVB only. The normalized data gave an $\mathrm{EC}_{50}$ value of $9.37 \mathrm{nM}$ indicating that the peptide remained bioactive after incorporating the $\mathrm{His}_{6}$-tag.

\section{Optimization of FLV Formulation to Maximize $\mathrm{Ni}^{2+}$ Tether Display}

To determine composition of FLV formulations that would optimally incorporate $\mathrm{Ni}^{+}$tethers in membranes, a series of experiments altering levels of DOGS-NTA-Ni ${ }^{2+}$ were performed. In previous studies (data not shown) which characterized the fusogenicity of FLVs formulated with DOPC-POPA mixtures, we had established that POPA levels are critical to the fusogenic properties of FLVs. In this study, we kept the levels of POPA constant while varying the levels of DOPC and DOGS-NTA-Ni ${ }^{2+}$. Fig. (2) shows that, as the levels of DOGS-NTA-Ni ${ }^{2+}$ were increased, $\mathrm{Ni}^{2+}$ tether incorporation appeared to peak significantly at concentrations between 64 and $75 \mathrm{ng} / \mu \mathrm{L}$.

\section{Functionalization of Cell Membranes with $\mathrm{Ni}^{2+}$ Tethers}

To further characterize the efficiency of FLVs in incorporating $\mathrm{Ni}^{2+}$ tethers in cell membranes, incubation time and dose response studies were performed. FLVs formulated with DOPC : POPA : DOGS-NTA-Ni ${ }^{2+}$ at molar percentages of 20:57:23 successfully incorporated $\mathrm{Ni}^{2+}$ tethers on SKOV3 cell membranes in a time-dependent manner (Fig. 3) and dose-dependent manner (Fig. 4). These results suggest that $\mathrm{Ni}^{2+}$ tether incorporation in membranes can be modulated and carefully controlled by altering FLV incubation time, FLV concentration or both.

\section{Quantification of C-His ${ }_{6}$ Levels on Cell Membranes}

To directly quantify anti-complement peptide levels coupled to $\mathrm{Ni}^{2+}$ tethers on the membrane surface, we performed preliminary studies using UV absorbance, and determined that a wavelength of $284 \mathrm{~nm}$ was optimal to discern C-His 6 levels diluted in PBS. Following FLVs/C-His $6(0.1 \mu \mathrm{g} / \mu \mathrm{L})$ treatment, the mean levels of three experiments showed that membrane-bound $\mathrm{C}^{-} \mathrm{His}_{6}$ was significantly higher $(94.4 \pm 8.4 \mu \mathrm{g})$ than in cells treated with $\mathrm{C}_{-} \mathrm{His}_{6}$ alone $(18.6 \pm 7.9 \mu \mathrm{g}, \mathrm{P}=0.0026)$. These results indicate that $\mathrm{C}-\mathrm{His}_{6}$ was not only binding to $\mathrm{Ni}^{+}$tethers incorporated in membranes but also binding non-specifically. Fig. (5) shows the calculated levels of $\mathrm{C}^{-} \mathrm{His}_{6}$ displayed per surface area of membrane.

\section{Time Course Experiments}

To determine whether membrane-localized anticomplement peptide would be displayed by cells for $48 \mathrm{~h}$, fibroblasts were treated with FLVs/C-His 6 therapy, and levels of $\mathrm{C}-\mathrm{His}_{6}$ were quantified at $0 \mathrm{~h}, 24 \mathrm{~h}$ and $48 \mathrm{~h}$ posttreatment. As shown in Fig. (6), C-His 6 display was stable

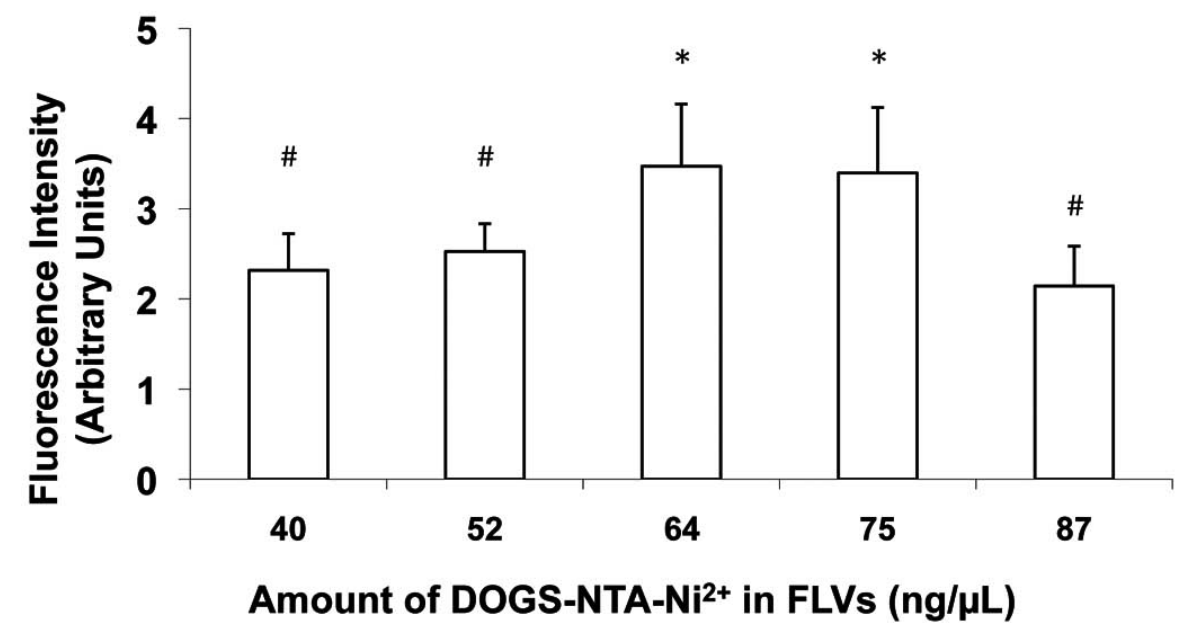

Fig. (2). Varying levels of DOGS-NTA-Ni ${ }^{2+}$ in FLV formulations altered $\mathrm{Ni}^{2+}$ tether incorporation in fibroblast cell membranes. Cells were incubated $(20 \mathrm{~min})$ with FLVs formulated with various molar ratios of DOPC : POPA : DOGS-NTA-Ni ${ }^{2+}$ ( $\mathrm{n}=8$ wells per formulation). Cells were washed and incubated $(30 \mathrm{~min})$ with a truncated $\mathrm{His}_{6}$-tagged protein (Cardiotrophin-His ${ }_{6}$ ), an additional wash was performed, and cells were incubated $\left(15 \mathrm{~min}\right.$ ) with FITC-labeled anti-His ${ }_{6}$ antibodies. FLVs formulated with 64 and $75 \mathrm{ng} / \mu \mathrm{L}$ of DOGS-NTA-Ni ${ }^{2+}$ bound greater amounts of Cardiotrophin-His ${ }_{6}$, indicating greater incorporation of $\mathrm{Ni}^{2+}$ tethers. Bars represent mean fluorescence levels $\pm \mathrm{SEM}$. $*$ indicates $\mathrm{P}<0.05$ compared to \#. 


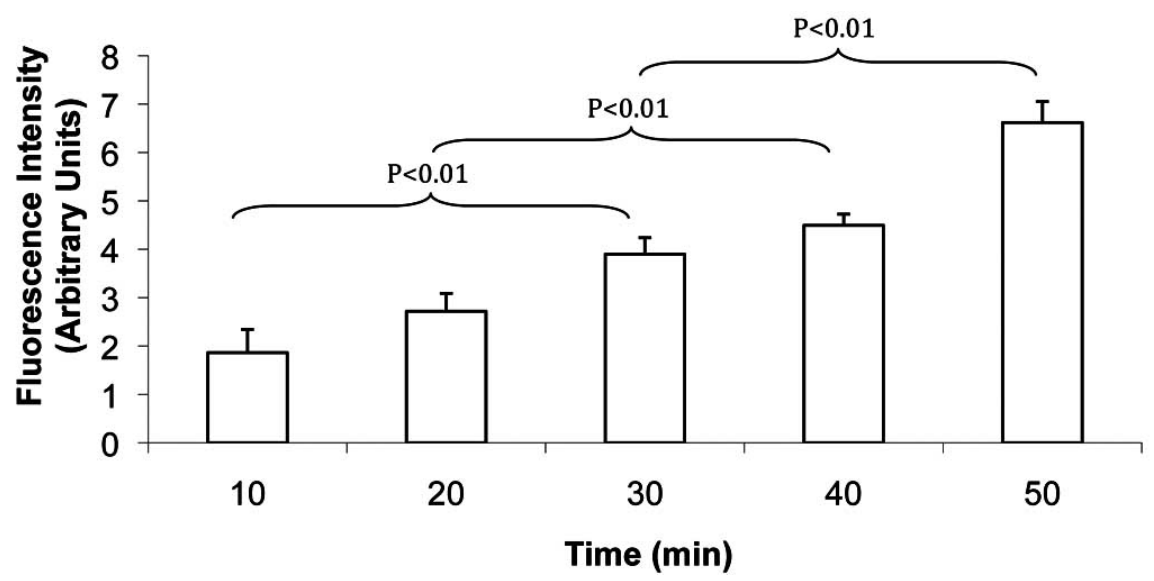

Fig. (3). FLV incubation incorporated $\mathrm{Ni}^{2+}$ tethers in cell membranes in a time-dependent manner. SKOV-3 cells were incubated with FLVs for various time periods ( $\mathrm{n}=8$ wells per time period). Cells were washed and incubated $(30 \mathrm{~min})$ with $\mathrm{C}$-His $\mathrm{H}_{6}$, an additional wash was performed, and cells were incubated (15 min) with FITC-labeled anti-His ${ }_{6}$ antibodies. Bars represent mean fluorescence levels \pm SEM.

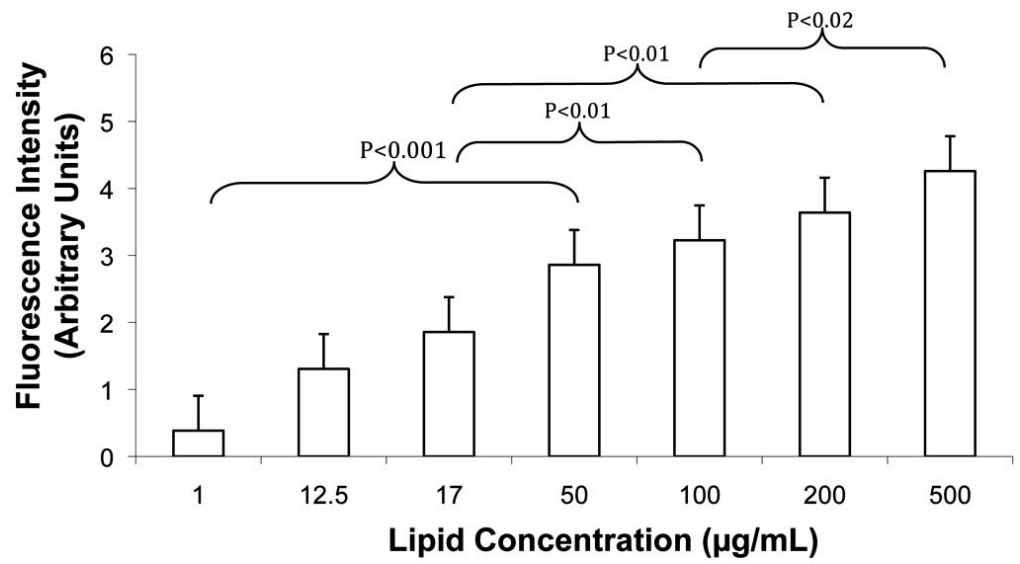

Fig. (4). Increasing FLV levels increased $\mathrm{Ni}^{2+}$ tether incorporation in SKOV-3 cell membranes in a dose-dependent manner. Cells were incubated (20 min) with various concentrations of FLVs ( $\mathrm{n}=8$ wells per lipid concentration). Cells were washed and incubated (30 min) with C$\mathrm{His}_{6}$, an additional wash was performed, and cells were incubated $(15 \mathrm{~min})$ with FITC-labeled anti-His ${ }_{6}$ antibodies. Bars represent mean fluorescence levels \pm SEM.

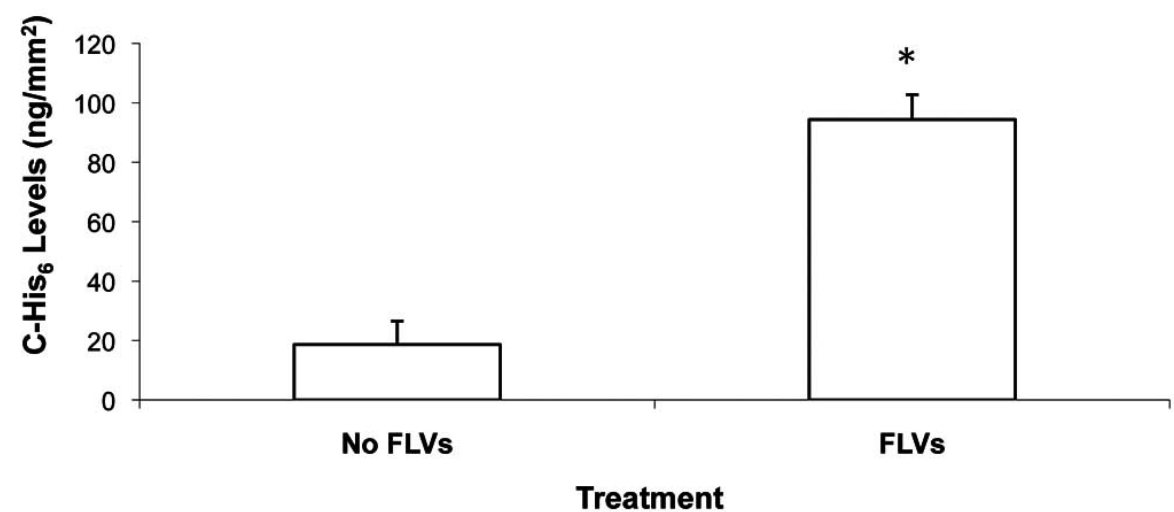

Fig. (5). Levels of $\mathrm{Ni}^{2+}$-tether-bound $\mathrm{C}-\mathrm{His}_{6}$ per area of cell membrane is shown. Cells (100\% confluence) in 12-well plates were incubated $(50 \mathrm{~min})$ with and without FLVs. Cells were washed and incubated $(30 \mathrm{~min})$ with $1 \mathrm{~mL}$ of $0.10 \mathrm{mg} / \mathrm{mL}$ of C-His ${ }_{6}$. Cells were washed, and membrane-bound $\mathrm{C}-\mathrm{His}_{6}$ was released by incubating cells for 10 min with $330 \mu \mathrm{L}$ of PBS (pH 4). To quantify C-His ${ }_{6}$, three $100 \mu \mathrm{L}$ aliquots from each well were drawn, placed in separate wells of a 96-well plate and UV absorbance was measured at $284 \mathrm{~nm}$. C-His 6 levels per surface area were calculated using a C-His ${ }_{6}$ standard curve and the surface area of the well's bottom $\left(38.3 \mathrm{~mm}^{2}\right)$. $*$ indicates $\mathrm{P}<0.05$ when compared to cells without FLV treatment.

over $48 \mathrm{~h}$. There was no statistical significance between mean $\mathrm{C}-\mathrm{His}_{6}$ levels released by the low $\mathrm{pH}$ buffer at the three time points. However, in all experiments there was a trend for higher $\mathrm{C}-\mathrm{His}_{6}$ levels released at $24 \mathrm{~h}$. 


\section{Complement C3b Deposition Assay}

To determine whether decoration of anti-complement peptide on cell surfaces would decrease complement activation efficiency, we used HER2/neu-overexpressing human ovarian carcinoma SKOV-3 cells. As shown in Fig. (7), antiHER2/neu antibody could bind to HER2/neu and potently activate complement leading to $\mathrm{iC} 3 \mathrm{~b}$ deposition (red line). The mean fluorescence intensity (MFI) as measured by flow cytometry of live SKOV-3 cells with anti-HER2/neu antibody plus fresh human serum as a source of complement was $189 \pm 171$. In contrast, MFI from SKOV-3 cells treated with FLVs and C-His 6 was significantly lower than that of untreated control cells, reflecting reduced $\mathrm{iC} 3 \mathrm{~b}$ deposition. Cells treated with the highest $\mathrm{C}-\mathrm{His}_{6}$ concentration, $0.2 \mathrm{mg} / \mathrm{mL}$ (orange line) had a MFI value of $79.1 \pm 43.9$ as compared to untreated control (red line) which had a MFI value of $189 \pm 171$ with $\mathrm{P}<0.01$ for both groups $(0.05 \mathrm{mg} / \mathrm{mL}$ and $0.2 \mathrm{mg} / \mathrm{mL}$ ). These data suggest that indeed localization of anti-complement peptide to cell surfaces significantly impairs potent complement activation.

\section{DISCUSSION}

We present a novel approach of incorporating small peptides onto the surface of cell membranes; an approach that has potential application in the development of anticomplement therapies. The purpose of this study was twofold. First, we wished to demonstrate that FLVs formulated with a novel combination of lipids can efficiently allow the display of a small anti-complement peptide on cell membranes for at least $48 \mathrm{~h}$. Second, we wanted to provide proof-

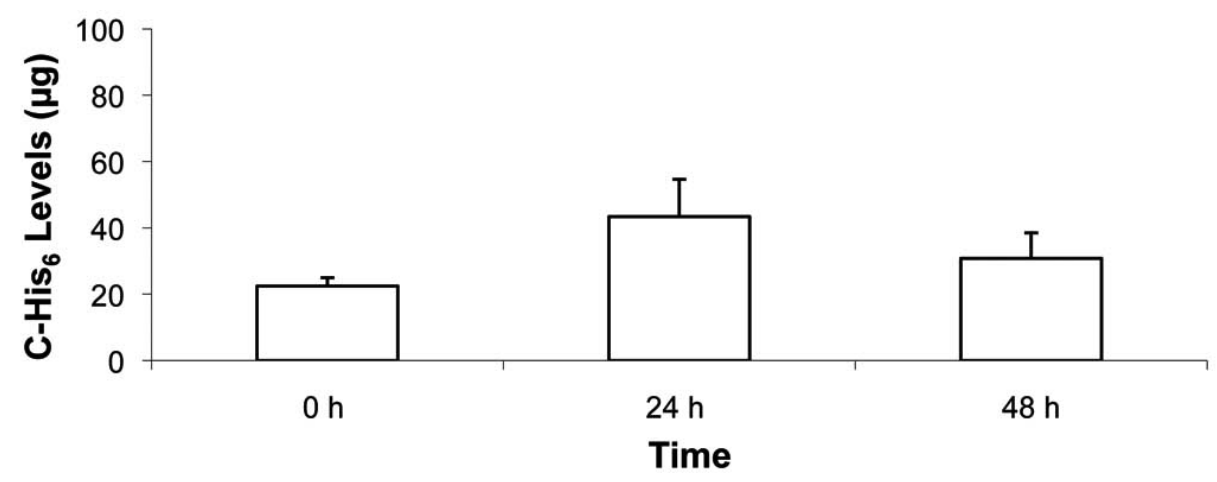

Fig. (6). Time course of C-His ${ }_{6}$ displayed on fibroblast membranes following FLV/C-His 6 treatment. Cells in 12-well plates were allowed to reach $\sim 90 \%$ confluence. Cells were incubated $(30 \mathrm{~min})$ with and without FLVs. Cells were washed and incubated (30 min) with $1 \mathrm{~mL}$ of 0.1 $\mathrm{mg} / \mathrm{mL}$ of C-His 6 . Cells were washed and incubated at $37^{\circ} \mathrm{C}$ in cell media for 0,24 and $48 \mathrm{~h}$. At the end of each time point, cells were washed, and membrane-bound C-His ${ }_{6}$ was released by incubating cells $(10 \mathrm{~min}$ ) with $330 \mu \mathrm{L}$ of PBS (pH 4$)$. To quantify C-His 6 , three $100 \mu \mathrm{L}$ aliquots from each well were drawn, placed in separate wells of a 96-well plate and UV absorbance was measured at $284 \mathrm{~nm}$. C-His 6 levels were calculated using a C-His 6 standard curve. Five experiments were combined and there was no statistical significance between the three time points.

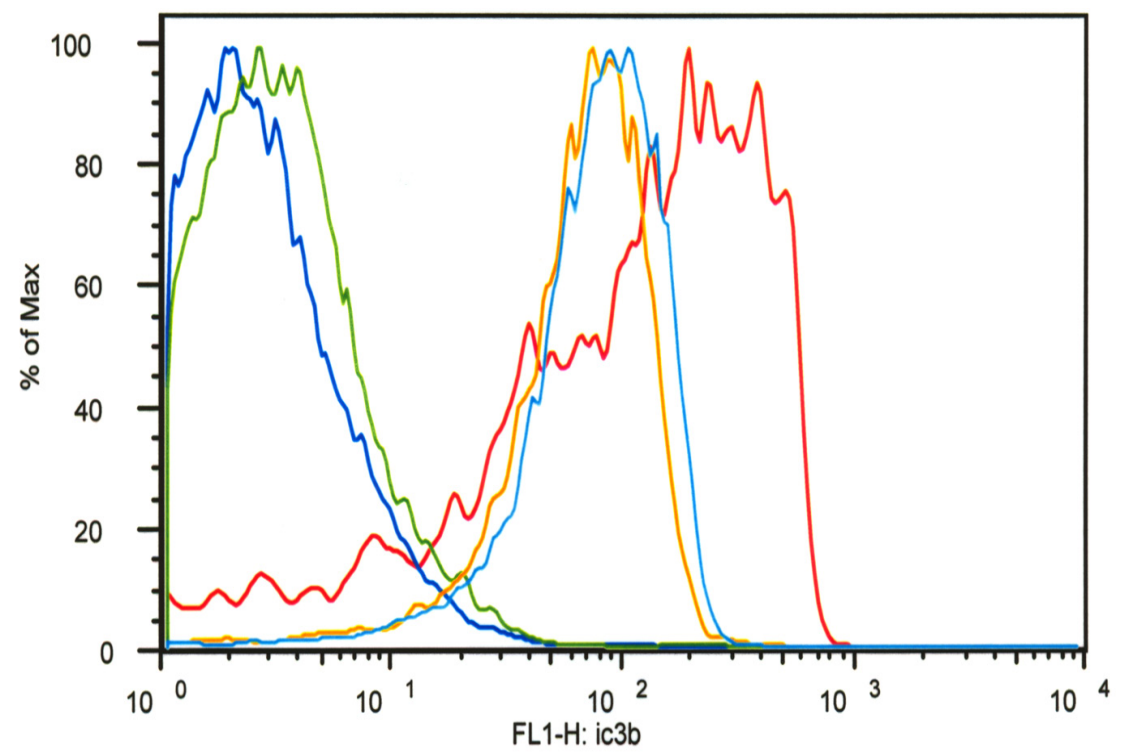

Fig. (7). Flow cytometry analysis demonstrated that decoration of SKOV-3 cells with C-His ${ }_{6}$ reduced complement deposition (C3b) in a classical activation assay. All cell groups except for the untreated controls (dark blue) were incubated with trastuzumab and FITC-labeled anti-C3b antibodies. One group was incubated without serum (green) to determine non-specific C3b antibody binding. One group served as the positive control (red) and two groups were treated with FLVs and C-His ${ }_{6}$ at two different concentrations: $0.05 \mathrm{mg} / \mathrm{mL}$ (light blue) and $0.2 \mathrm{mg} / \mathrm{mL}$ (orange). FLVs $/ \mathrm{C}-\mathrm{His}_{6}(0.2 \mathrm{mg} / \mathrm{mL}$ and $0.05 \mathrm{mg} / \mathrm{mL})$ treatment reduced C3b deposition significantly compared to untreated positive controls with $\mathrm{P}<0.01$. 
of-concept that the membrane-immobilized peptide is able to reduce complement deposition in a classical activation assay. Our data provides evidence that the lipids used in our FLV formulation produced vesicles that rapidly fused with cells without the aid of fusogens, and after FLV treatment, cell membranes were functionalized with $\mathrm{C}-\mathrm{His}_{6}$, protecting cells from complement activation.

In the literature, various approaches have been reported to modify cell membranes with proteins in vitro [26-29]. In some approaches, proteins were derivatized to permit their direct anchorage to cell membranes by adding lipophilic moieties to proteins such as: glycosyl phosphatidylinositol [26], palmitic acid [28], and hydrophobic tails [27]. Another approach involved the biotinylation of endogenous membrane proteins with sulfo-NHS-LC-biotin to anchor streptavidin-containing chimeric proteins [29]. Although all approaches were effective in decorating cells, there were differences in the time course of display. However, short-term or long-term protein display needs to be considered in the context of the therapeutic agent's activity requirements.

Liposomes have not been used extensively to modify cell membranes although this potential clearly exists. Liposomes can be shaped and formulated to work either as long-acting sustained release vesicles (low fusogenicity) for drug delivery or as fusogenic vesicles for intracellular delivery of various agents [16, 17, 30-37]. When fusogenic vesicles merge with cells, their lipids incorporate into plasma membranes and provide an opportunity to modify the cell surface. Two research teams have reported modification of cell membranes using fusogenic vesicles. Fadok et al. performed an in vitro study in which $\mathrm{T}$ cells treated with fusogenic liposomes formulated with phosphatidylserine induced co-cultured macrophages to engulf what appeared to be apoptotic $\mathrm{T}$ cells [38]. van Broekhoven et al., in the process of developing a cancer vaccine, formulated liposomes with $\alpha$-palmitoyl- $\beta$ oleoyl-phosphatidylcholine (POPC) and a zinc-chelating lipid, nitrilotriacetic acid di-tetradecylamine (NTA-DTDA), to display $\mathrm{His}_{6}$-tagged recombinant co-stimulatory molecules on murine P815 tumor cells [18]. Using this technique, mice immunized with P815 tumor cells bearing B7.1 and CD40 demonstrated an increased cytolytic T-lymphocyte activity against P815 cells and inhibited tumor growth. However, their approach had some shortcomings. The vesicle's lipid formulation and construction was not optimal for promoting fusion with cells and required the aid of a fusogen (i.e., polyethylene glycol). The time course of protein display was relatively short, protein levels (measured using fluorescence intensity) decreased rapidly from $\sim 400$-fold (immediately after treatment) to $\sim 60$-fold and $\sim 15$-fold by 4 and $24 \mathrm{~h}$, respectively. The authors attributed the loss of displayed protein to a predominant internalization of the NTA-DTDAprotein complex by the cell [18]. In the present study, the levels of $\mathrm{C}$-His ${ }_{6}$ displayed on the membrane surface did not change significantly over $48 \mathrm{~h}$. These results are very different from those obtained by van Broekhoven et al., and we attribute the longer duration of peptide display in our study to important differences in lipid vesicle formulation, which promote vesicle-to-cell fusion without the use of fusogens like polyethylene glycol (see comments below). Once fusion occurred and vesicle lipids incorporated in the cell membrane, we did not observe changes that would suggest internalization of the DOGS-NTA-Ni ${ }^{2+}$-peptide complex. We observed the opposite, at $24 \mathrm{~h}$ there was a trend of increasing ${\mathrm{C}-\mathrm{His}_{6}}_{6}$ levels being released from DOGS-NTA-Ni ${ }^{2+}$. This non-significant trend $(\mathrm{P}=0.0825)$ may represent release of either non-specific bound $\mathrm{C}_{\text {-His }} 6$ or internalized peptide, which interacted and coupled with empty $\mathrm{Ni}^{+}$tethers over the first $24 \mathrm{~h}$ period, and later released by the low $\mathrm{pH}$ PBS incubation, producing the apparent trend.

The construction and formulation of FLVs used in the present study differed from those presented by van Broekhoven et al. [18]. Our FLV formulation consisted of DOPC, POPA and DOGS-NTA-Ni ${ }^{2+}$, which was different from their formulation (POPC and NTA-DTDA). To increase FLV instability and enhance fusion with cells, we added an asymmetric lipid (POPA) to disrupt homogeneity of the lipid bilayer. Furthermore, our FLVs were created with a highfrequency sonicator, to produce vesicle populations with a tight radius of curvature $(\sim 125 \mathrm{~nm})$, which increases instability of FLV membranes and enhances fusion with cells. Our approach did not require any fusogens to boost incorporation of DOGS-NTA-Ni ${ }^{2+}$ into the cell membrane. Another important difference between the two approaches is that $\mathrm{Ni}^{2+}$ was chelated to the lipid before FLV construction eliminating the need to add ionized divalent metal to the incubation buffer (a potential source for toxicity) during vesicle-cell fusion. Finally, the therapeutic goal of our approach was not vaccine development, but rather to reduce IRI by reinforcing endogenous complement control proteins expressed on cell membranes with an anti-complement peptide.

The ability to locally deliver complement inhibitors in an efficient manner to sites of inflammation can have tremendous benefits in complement-mediated pathology. One obvious application is in tissue transplantation, which by definition has to undergo IR. In most tissues prolonged IR is known to cause endothelial cell dysfunction due to abnormal increases in the reactive oxygen species, increased expression of adhesion molecules and complement activation [1, 39-43]. All these factors can contribute toward the functional impairment of the endothelial barrier, thereby leading to protein extravasation and interstitial edema. Several studies have also shown that complement activation induced by IR leads to the formation of key inflammatory mediators (C3a, $\mathrm{C} 5 \mathrm{a}, \mathrm{C} 3 \mathrm{~b}$ and C5b-9) that alter vascular homeostasis and stimulate leukocyte activation and chemotaxis [44]. Following transplantation pathological changes observed in the grafts have been linked to increased complement activation. Normally endothelial cells express complement regulatory proteins to self-protect from continuous low-level complement activity in plasma [8]. However, in transplanted grafts following IR, these defenses are rapidly overwhelmed and endothelial cell damage and dysfunction ensues. Our therapeutic approach can enhance endogenous complement control proteins and reduce tissue injury following IR.

Although sCR1 and anti-C5 monoclonal antibody have been successful in offering protection against IRI [45, 46], long-term systemic inhibition of complement can lead to infections and auto-immune diseases [47, 48]. Alternative targeted approaches are being developed, including membrane targeting strategies $[8,9,13]$. sCR1sLex (TP20) consisting of soluble CR1 decorated with fucosylated tetrasaccharide sialyl Lewisx, targets sLex binding sites on Eselectin and P-selectin adhesion molecules expressed on the 
endothelium after IR. sCR1-3-MSWP1 (APT070), CD59MSWP1 and DAF-MSWP1 consist of fragments of natural complement control proteins coupled to the membrane targeting peptide 1 (MSWP1). In animal models of transplantation and IR injury, TP20 and APT070 have been shown to be effective [11, 14, 49, 50]. Although cell membrane-targeted agents appear to be promising in IRI animal studies, none have been approved for this indication by the FDA [15].

\section{CONCLUSION}

In summary, in this study we selected and modified an anti-complement peptide to work with our FLV delivery system. FLVs allowed control of displayed peptide levels by varying formulation, incubation time, and/or concentration of FLVs. The peptide remained anchored to the site of complement activation for at least 2 days. Based on the results, we conclude that our FLV approach to deliver small peptides has potential for local treatment of tissues to reduce IRinduced complement activation. Our approach appears to be well suited for ex vivo treatment of organs in transplantation. However, to assess efficacy in vivo, future studies will need to be performed in primates since $\mathrm{C}$ only inhibits primatederived complement.

\section{ABBREVIATIONS}

\begin{tabular}{|c|c|c|}
\hline ANOVA & $=$ & Analysis of variance \\
\hline $\mathrm{C}$ & $=$ & Compstatin \\
\hline DMEM & $=$ & Dulbecco's Modified Eagle's Medium \\
\hline DOGS-NTA-Ni ${ }^{2+}$ & $=$ & $\begin{array}{l}\text { 2-Dioleoyl-sn-Glycero-3-\{[N(5- } \\
\text { Amino-1- } \\
\text { Carboxypentyl)iminodiacetic } \\
\text { acid]succinyl }\} \text { (nickel salt) }\end{array}$ \\
\hline DOPC & $=$ & $\begin{array}{l}\text { 1,2-Dioleoyl-sn-Glycero-3- } \\
\text { Phosphocholine }\end{array}$ \\
\hline FBS & $=$ & Fetal bovine serum \\
\hline FDA & $=$ & US Food and Drug Administration \\
\hline FITC & $=$ & Fluorescein isothiocyanate \\
\hline FLVs & $=$ & Fusogenic lipid vesicles \\
\hline GVB & $=$ & Gelatin veronal buffer \\
\hline $\mathrm{His}_{6}$ & $=$ & Hexahistidine \\
\hline HPLC & $=$ & $\begin{array}{l}\text { High Performance Liquid Chroma- } \\
\text { tography }\end{array}$ \\
\hline IR & $=$ & Ischemia/reperfusion \\
\hline IRI & $=$ & Ischemia/reperfusion injury \\
\hline MFI & $=$ & Mean fluorescence intensity \\
\hline MSWP 1 & $=$ & $\begin{array}{l}\text { Myristoylated electrostatic switch } \\
\text { peptide } 1\end{array}$ \\
\hline $\mathrm{Ni}^{2+}$ & $=$ & Nickel \\
\hline $2 \mathrm{Nal}$ & $=$ & 2-naphthylalanine \\
\hline NTA-DTDA & $=$ & $\begin{array}{l}\text { Nitrilotriacetic acid di-tetradecyl- } \\
\text { amine }\end{array}$ \\
\hline PBS & $=$ & Phosphate buffered saline \\
\hline
\end{tabular}

$\begin{array}{lll}\text { POPA } & =\begin{array}{l}\text { 1-Palmitoyl-2-Oleoyl-sn-Glycero-3- } \\ \text { Phosphate(monosodium salt) }\end{array} \\ \text { SCR1 } & \text { Soluble complement receptor1 } \\ \text { SEM } & = & \text { Standard error of mean } \\ \text { SKOV-3 } & = & \text { Ovarian carcinoma cells } \\ \text { UV } & = & \text { Ultraviolet }\end{array}$

\section{CONFLICT OF INTEREST}

The authors acknowledge that there is a financial conflict of interest.

\section{ACKNOWLEDGEMENTS}

This work was funded in part by grants from the National Institutes of Health R41 HL079855 and from EndoProtech, Inc. Louisville, KY.

\section{REFERENCES}

[1] Hill JH, Ward PA. The phlogistic role of C3 leukotactic fragments in myocardial infarcts of rats. J Exp Med 1971; 133(4): 885-900.

[2] Amsterdam EA, Stahl GL, Pan HL, Rendig SV, Fletcher MP, Longhurst JC. Limitation of reperfusion injury by a monoclonal antibody C5a during myocardial infarction in pigs. Am J Physiol 1995; 268: H448-H457.

[3] Smith GW, McArthur CJ, Simpson IJ. Circulating immune complexes in myocardial infarction. J Clin Lab Immunol 1983; 12(4): 197-9.

[4] Weiser MR, Williams JP, Moore FD Jr, et al. Reperfusion injury of ischemic skeletal muscle is mediated by natural antibody and comment. J Exp Med 1996; 183(5): 2343-8.

[5] Platt JL, Saadi S. The role of complement in transplantation. Mol Immunol 1999; 36: 965-71.

[6] Eltzschig HK, Collard CD. Vascular ischaemia and reperfusion injury. Br Med Bull 2004; 70:71-86.

[7] Stahl GL, Xu Y, Hao L, et al. Role for the alternative complement pathway in ischemia/reperfusion injury. Am J Pathol 2003; 162(2): 449-5.

[8] Morgan BP, Meri S. Membrane proteins that protect against complement lysis. Springer Semin Immunopathol 1994; 15(4): 369-96.

[9] Harris CL, Fraser DA, Morgan BP. Tailoring anti-complement therapeutics. Biochem Soc Trans 2002; 30: 1019-26.

[10] Smith GP, Smith RA. Membrane-targeted complement inhibitors. Mol Immunol 2001; 38(2-3): 249-55.

[11] Linton SM, Williams AS, Dodd I, Smith R, Williams BD, Morgan BP. Therapeutic efficacy of a novel membrane-targeted complement regulator in antigen-induced arthritis in the rat. Arthritis Rheum 2000; 43(11): 2590-7.

[12] Patel H, Smith RA, Sacks SH, Zhou W. Therapeutic strategy with a membrane-localizing complement regulator to increase the number usable donor organs after prolonged cold storage. J Am Soc Nephrol 2006; 17(4): 1102-11.

[13] Rehrig S, Fleming SD, Anderson J, et al. Complement inhibitor, complement receptor 1-related gene/protein y-Ig attenuates intestinal damage after the onset of mesenteric ischemia/reperfusion injury in mice. J Immunol 2001; 167(10): 5921-7.

[14] Stammberger U, Hamacher J, Hillinger S, Schmid RA. sCR1sLe ameliorates ischemia/reperfusion injury in experimental lung transplantation. J Thorac Cardiovasc Surg 2000; 120(6):1078-84.

[15] Ricklin D, Lambris JD. Complement-targeted therapeutics. Nat Biotechnol 2007; 25(11): 1265-75

[16] Pagano RE, Weinstein JN. Interactions of liposomes with mammalian cells. Annu Rev Biophys Bioeng 1978; 7: 435-68.

[17] Banerjee R. Liposomes: Applications in medicine. J Biomater Appl 2001; 16(3): 3-21.

[18] van Broekhoven CL, Parish CR, Vassiliou G, Altin JG. Engrafting costimulator molecules onto tumor cell surfaces with chelator lipids: a potentially convenient approach in cancer vaccine development. J Immunol 2000; 164(5): 2433-43.

[19] Katragadda M, Magotti P, Sfyroera G, Lambris JD. Hydrophobic effect and hydrogen bonds account for the improved activity of a 
complement inhibitor, compstatin. J Med Chem 2006; 49(15): 4616-22.

[20] Klepeis JL, Floudas CA, Morikis D, et al. Integrated computational and experimental approach for lead optimization and design of compstatin variants with improved activity. J Am Chem Soc 2003; 125(28): 8422-3.

[21] Morikis D, Roy M, Sahu A, et al. The structural basis of compstatin activity examined by structure-function-based design of peptide logs and NMR. J Biol Chem 2002; 277(17): 1494253.

[22] Soulika AM, Morikis D, Sarrias MR, et al. Studies of structureactivity relations of complement inhibitor compstatin. J Immunol 2003; 171(4): 1881-90.

[23] Mallik B, Katragadda M, Spruce LA, et al. Design and NMR characterization of active analogues of compstatin containing nonnatural amino acids. J Med Chem 2005; 48(1): 274-86.

[24] Morgan BP. Methods in molecular biology. 1st ed. Totowa, NJ: Humana Press Inc. 2000.

[25] Roederer M, Treister A, Moore W, Herzenberg LA. Probability binning comparison: a metric for quantitating univariate distribution differences. Cytometry 2001; 45(1): 37-46.

[26] Zhang F, Schmidt WG, Hou Y, Williams AF, Jacobson K. Spontaneous incorporation of the glycosyl-phosphatidylinositol-linked protein Thy-1 into cell membranes. Proc Natl Acad Sci USA 1992; 89(12): 5231-5.

[27] Wahlsten JL, Mills CD, Ramakrishnan S. Antitumor response elicited by a superantigen-transmembrane sequence fusion protein anchored onto tumor cells. J Immunol 1998; 161(12): 6761-7.

[28] Chen A, Zheng G, Tykocinski ML. Hierarchical costimulator thresholds for distinct immune responses: application of a novel two-step Fc fusion protein transfer method. J Immunol 2000; 164(2): 705-11.

[29] Yolcu ES, Askenasy N, Singh NP, Cherradi SE, Shirwan H. Cell membrane modification for rapid display of proteins as a novel means of immunomodulation: FasL-decorated cells prevent islet graft rejection. Immunity 2002; 17(6): 795-808.

[30] Allen TM. Liposomes. Opportunities in drug delivery. Drugs 1997; 54(Suppl 4): 8-14.

[31] Fraley R, Straubinger RM, Rule G, Springer EL, Papahadjopoulos D. Liposome-mediated delivery of deoxyribonucleic acid to cells: enhanced efficiency of delivery related to lipid composition and incubation conditions. Biochemistry 1981; 20(24): 697887.

[32] Garrett FE, Goel S, Yasul J, Koch RA. Liposomes fuse with sperm cells and induce activation by delivery of impermeant agents. Biochim Biophys Acta 1999; 1417(1): 77-88.

[33] Kozubek A, Gubernator J, Przeworska E, Stasiuk M. Liposomal drug delivery, a novel approach: PLARosomes. Acta Biochim Pol 2000; 47(3): 639-49.

[34] Schiffelers R, Storm G, Bakker-Woudenberg I. Liposomeencapsulated aminoglycosides in pre-clinical and clinical studies. J Antimicrob Chemother 2001; 48(3): 333-44.
[35] Trigiante G, Huestis WH. Selective virus-mediated intracellular delivery of membrane-impermeant compounds by means of plasma membrane vesicles. Antiviral Res 2000; 45(3): 211-21.

[36] Khatri K, Rawat A, Mahor S, Gupta PN, Vyas SP. Hepatitis B surface protein docked vesicular carrier for site specific delivery to liver. J Drug Target 2005; 13(6): 359-66.

[37] Zakaria eR, Ehringer WD, Tsakadze N, Li N, Garrison RN. Direct energy delivery improves tissue perfusion after resuscitated shock. Surgery 2005 138(2):195-203.

[38] Fadok VA, Voelker DR, Campbell PA, Cohen JJ, Bratton DL, Henson PM. Exposure of phosphatidylserine on the surface of apoptotic lymphocytes triggers specific recognition and removal by macrophages. J Immunol 1992; 148(7): 2207-2216.

[39] Halliwell B, Gutteridge JM, Cross CE. Free radicals, antioxidants, and human disease: where are we now? J Lab Clin Med 1992; 119(6): 598-620.

[40] Kalayoglu M, Sollinger HW, Stratta RJ, et al. Extended preservation of the liver for clinical transplantation. Lancet 1988; 1(8586): 617-9.

[41] Lominadze D, Saari JT, Miller FN, Catalfamo JL, Schuschke DA. Von Willebrand factor restores impaired platelet thrombogenesis in copper-deficient rats. J Nutr 1997; 127(7): 1320-7

[42] Weisman HF, Bartow T, Leppo MK, et al. Soluble human complement receptor type 1: in vivo inhibitor of complement suppressing post-ischemic myocardial inflammation and necrosis. Science 1990; 249(4965): 146-51.

[43] Wink DA, Wink CB, Nims RW, Ford PC. Oxidizing intermediates generated in the Fenton reagent: kinetic arguments against the intermediacy of the hydroxyl radical. Environ Health Perspect 1994 102(Suppl 3): 11-15.

[44] Mollnes TE, Song WC, Lambris JD. Complement in inflammatory tissue damage and disease. Trends Immunol 2002; 23(2): 61-4.

[45] Pratt JR, Hibbs MJ, Laver AJ, Smith RA, Sacks SH. Effects of complement inhibition with soluble complement receptor-1 on vascular injury and inflammation during renal allograft rejection in the rat. Am J Pathol 1996; 149(6): 2055-66.

[46] Vakeva AP, Agah A, Rollins SA, Matis LA, Li L, Stahl GL. Myocardial infarction and apoptosis after myocardial ischemia and reperfusion: role of the terminal complement components and inhibition by anti-C5 therapy. Circulation 1998; 97(22): 2259-67.

[47] Figueroa JE, Densen P. Infectious diseases associated with complement deficiencies. Clin Microbiol Rev 1991; 4(3): 359-95.

[48] Sullivan KE. Complement deficiency and autoimmunity. Curr Opin Pediatr 1998; 10(6): 600-6.

[49] Dong J, Pratt JR, Smith RA, Dodd I, Sacks SH. Strategies for targeting complement inhibitors in ischaemia/reperfusion injury. Mol Immunol 1999; 36(13-14): 957-63.

[50] Zacharowski K, Otto M, Hafner G, Marsh HC, Jr, Thiemermann C. Reduction of myocardial infarct size with sCR1sLe(x), an alternatively glycosylated form of human soluble complement receptor type 1 (sCR1), possessing sialyl Lewis x. Br J Pharmacol 1999; 128(5): 945-52.

Received: May 18, 2010

Revised: May 28, 2010

Accepted: May 31, 2010

(C) Goga et al.; Licensee Bentham Open.

This is an open access article licensed under the terms of the Creative Commons Attribution Non-Commercial License (http://creativecommons.org/licenses/ by-nc/3.0/) which permits unrestricted, non-commercial use, distribution and reproduction in any medium, provided the work is properly cited. 